DOI https://doi.org/10.30525/978-9934-588-92-1-78

\title{
ДО ПИТАННЯ ЩОДО СУБ'ЄКТА ФАЛЬСИФІКАЦІЇ ДОКАЗІВ ЗА КРИМІНАЛЬНИМ ЗАКОНОДАВСТВОМ УКРАЇНИ
}

\author{
Нікітенко В. М. \\ кандидат юридичних наук, \\ дочент кафедри правового забезпечення безпеки бізнесу
}

Київського начіонального торговельно-економічного університету м. Київ, Украӥна

У теорії кримінального права відмічається, що фізична, осудна особа, яка досягла встановленого законом віку кримінальної відповідальності, прийнято називати загальним суб'єктом злочину. Ці теоретичні положення втілені законодавцем у ст. 18 КК України.. Спеціальний суб'єкт - це особа, яка, крім обов'язкових загальних ознак (фізична, осудна особа, що досягла певного віку), має додаткові спеціальні (особливі) ознаки, які прямо передбачені в статті Особливої частини КК для суб'єкта конкретного складу кримінального правопорушення. В інших же випадках, хоча в самому законі прямо i не названий спеціальний суб'єкт, але саме кримінальне правопорушення припускає його наявність.

Ознаки спеціального суб'єкта певною мірою є обмежувальними, оскільки вони визначають, що той чи інший злочин може вчинити не будь-яка, а тільки та особа, яка має такі ознаки [1, с. 150].

КК не містить спеціальної статті, якою передбачено відповідальність за фальсифікацію доказів, тому такі діяння кваліфікуються за іншими статтями Особливої частини цього Кодексу.

Отже, правильне встановлення суб'єкта діянь, пов'язаних із фальсифікацією доказів, безпосередньо впливає на кримінальноправову кваліфікацію кримінальних правопорушень, передбачених ст.ст. 358, 364-366, 373, 384, 386 КК України, та виключає можливість притягнення до кримінальної відповідальності інших осіб за їх вчинення.

В юридичній літературі зазначено, що суб'єкт злочинів, передбачених ст.ст. 364-366, 373, 384 КК України, може бути лише спеціальний, а саме службова особа, працівник правоохоронного органу, свідок, потерпілий, експерт, оцінювач майна та перекладач [2, c. 1057,$1075 ; 3$, c. $269,284,287]$. 
У зв'язку 3 тим, що кримінальне провадження має низку відмінностей порівняно із іншими формами судочинства, тому суб'єкти фальсифікації доказів різняться.

Так, І.С. Благодарь вказує, що у цивільній та адміністративній формах судочинства суб'єктом фальсифікації процесуально визначених доказів, зокрема документів та речових доказів, можуть бути: 1) особи, які беруть участь у справі; 2) представники цих осіб [4, с. 103]. 3 цього приводу постає питання, чи є вказані особи загальним або спеціальним суб’єктом злочинів, зокрема у сфері фальсифікації доказів.

На думку С.В. Асташова, суб'єкт фальсифікації доказів у цивільній справі повинен бути наділений процесуальною правосуб'єктністю, оскільки для того, щоб особа здатна була б вчиняти у процесі юридично значимі як правомірні, так i протиправні дії, які спричиняють шкоду охоронюваним кримінальним законом відносинам, необхідно ій мати також можливість самостійно виконувати свої процесуальні права та обов'язки [5, с. 13].

Цивільна процесуальна правоздатність осіб, які беруть участь у справі, регламентована ст. 28 ЦПК України та визначається як здатність мати цивільні процесуальні права та обов'язки, а цивільна процесуальна дієздатність - здатність особисто здійснювати цивільні процесуальні права та виконувати свої обов'язки в суді передбачена ст. 29 ЦПК України. Аналогічні положення для вказаних осіб закріплені адміністративним та господарським процесуальними законодавствами (ст. 48 КАС України, ст.ст. 22, 28 ГПК України).

Отже, особи, які беруть участь у справах цивільної, адміністративної та господарської форм судочинства, набувають додаткових й обмежувальних ознак, які характеризують їх як спеціального суб'єкта кримінального правопорушення, у тому числі передбаченого ст. 358 КК України. Із наведеного випливає, що зазначені особи, які вчиняють описані у диспозиції цієї статті протиправні діяння із офіційними документами, що є доказами та письмовими доказами, мають ознаки спеціального суб'єкта вказаного кримінального правопорушення. Даний факт вказує на протиріччя між теоретичними положеннями кримінального права та законодавчим закріпленням суб'єкта кримінального правопорушення, передбаченого ст. 358 КК України в цій частині.

Найбільш потенційними «фальсифікаторами» у кримінальному провадженні виступає сторона обвинувачення, серед якої можна виділити слідчого та прокурора. Вказані особи є спеціальним суб'єктом кримінальних правопорушень, передбачених ст. 364-366, 373 КК України, що вчиняються у сфері фальсифікації доказів, не лише як 
службові особи, а ще й додатково наділені низкою процесуальних повноважень.

Заслуговує на увагу такий спеціальний суб'єкт кримінального правопорушення, передбаченого ст. 373 КК України, як працівник підрозділу, який здійснює оперативно-розшукову діяльність. Під час виконання доручень слідчого, прокурора цей працівник користується повноваженнями слідчого, а також безпосередньо формує доказ та подає його слідчому, прокурору, тому може вчиняти незаконні дії із доказами, у тому числі штучне його створення. Такий спеціальний суб'єкт також притягується до відповідальності за ст.ст. 364-366 КК України.

Сторона захисту сторона захисту має визначені $\S 3$ КПК України обов'язки, що свідчить про наявність у неї процесуальної правоздатності. А процесуальна дієздатність цієї сторони кримінального провадження регламентована ч. 5 ст. 22, ст. 42 КПК України, якою передбачено, що підозрюваний або обвинувачений здійснюють захист особисто або за допомогою захисника. Таким чином, сторона захисту набуває додаткових й обмежувальних ознак, які виокремлюють iï із загального суб'єкта та надають статус спеціального суб'єкта злочину.

Отже, сторона захисту, завдяки закріпленому нормами КПК України правовому статусу у кримінальному провадженні, що визначає іï як спеціального суб'єкта злочину, поряд із стороною обвинувачення, може вчиняти діяння, пов'язані із фальсифікацією доказів на стадіях досудового розслідування та судового провадження. Проте, сторона захисту не віднесена до категорії службових осіб, тому вчинення 3 їх боку фальсифікація доказів за чинним КК України не визнається злочином, оскільки відсутні такі його елементи, як спеціальний суб'єкт та об'єктивна сторона. У зв'язку з цим, учасники кримінального провадження, які віднесені до сторони захисту, при вчиненні протиправних дій із доказами не можуть бути притягнуті до кримінальної відповідальності.

Варто вказати, що захисник-адвокат є найбільш юридично підготовленим з боку сторони захисту та наявність передбачених законом прав може призвести до зловживань 3 його боку. Адже, досить вагомі повноваження адвоката як захисника у кримінальному провадженні та гарантії адвокатської діяльності передбачені Законом України «Про адвокатуру та адвокатську діяльність». Саме ці обставини наділяють захисника-адвоката додатковими та обмежувальними ознаками спеціального суб'єкта злочину.

Стосовно підозрюваного, обвинуваченого, то, видається, подання ними слідчому, прокурору, слідчому судді, суду сфальсифікованих доказів, $є$ одним із способів захисту, тому не має сенсу виокремлювати цих осіб із сторони захисту як спеціального суб'єкта вказаних злочинів. 318 
Щодо інших учасників кримінального провадження - свідка, потерпілого, експерта, перекладача, спеціаліста, оцінювача майна, які приймають безпосередню участь у формуванні доказів, то заборона на фальсифікацію окремих процесуально визначених доказів передбачена ст. 384 КК України. 3 огляду на диспозицію цієї статті вказані особи $\epsilon$ спеціальні суб'єкти кримінального правопорушення.

Таким чином, суб'єкт фальсифікації доказів незалежно від формі судочинства $\epsilon$ спеціальний, що наділений процесуальною правосуб'єктністю, за виключенням кримінального правопорушення, передбаченого ст. 386 КК України, суб'єкт якого загальний.

Проте, незважаючи на наявність обмежуючих та додаткових ознак, не віднесено на законодавчому рівні до спеціальних суб'єктів фальсифікації доказів наступних учасників процесу: 1) у цивільній, адміністративній та господарській формах судочинства - осіб, які беруть участь у справі та їх представників; 2) у кримінальному провадженні - захисника-адвоката.

У зв'язку з цим, деякі діяння, пов'язані із протиправними маніпуляціями із доказами, вчиненні вказаними особами, не визнані кримінально караними за ознакою суб'єкта кримінального правопорушення, що вказує на недосконалість вітчизняного кримінального закону у сфері протидії фальсифікації доказів.

\section{Література:}

1. Кримінальне право України. Загальна частина: підручник / М. І. Бажанов, Ю. В. Баулін, В. І. Борисов та ін.; за ред. М. І. Бажанова, В. В. Сташиса, В. Я. Тація. 2-ге вид., перероб. і допов. Київ : Юрінком Інтер, 2005. $480 \mathrm{c}$.

2. Кримінальний кодекс України: Науково-практичний коментар / Ю. В. Баулін, В. І. Борисов, С. Б. Гавриш та ін.; за заг. ред. В. В. Сташиса, В. Я. Тація. Київ : Концерн «Видавничий Дім «Ін Юре», 2003. $1196 \mathrm{c}$.

3. Стеблинська О. С. Кримінальне право. Особлива частина. Київ : Ін-т крим.-викон. служби, 2014. 358 с.

4. Благодарь И. С. Фальсификация доказательств (ответственность и вопросы квалификации): дис. ...канд. юрид. наук. Москва, 2008. 221 с.

5. Асташов С. В. Фальсификация доказательств по гражданському делу (части 1 и 3 статьи 303 УК РФ): Проблемы уголовно-правовой регламентации и квалификации: автореф. дис. ... канд. юрид. наук. Москва, 2013. 29 с. 